Studia Anglica Posnaniensia 49/3, 2014

doi: 10.1515/stap-2015-0007

\title{
COURTESY AND POLITENESS IN SIR GAWAIN AND THE GREEN KNIGHT
}

ANDREAS H. JUCKER

University of Zurich

\begin{abstract}
A close reading of three selected passages of the Middle English alliterative romance Sir Gawain and the Green Knight provides a detailed picture of fictional and fairy-tale manifestations of courtly and polite behaviour in Middle English, a period that imported many new terms of courtesy and politeness from French. In the three passages Sir Gawain is visited in his bedchamber by the lady of the house, who tries to seduce him and thus puts him in a severe dilemma of having to be courteous to the lady and at the same time loyal to his host and to the code of chivalry. The analysis shows how Sir Gawain and the lady of the house engage in a discursive struggle of the true implications of courteous behaviour. It also shows how the two characters use nominal and pronominal terms of address to negotiate their respective positions of power, dominance and submission towards each other. And, finally, an analysis of requests reveals how the lady carefully selects appropriate strategies to reflect the severity of the imposition of her requests and her momentary standing in their discursive struggle.
\end{abstract}

Keywords: historical pragmatics, Middle English, politeness, courtesy, Middle English romance, Sir Gawain and the Green Knight, terms of address

\section{Introduction ${ }^{1}$}

The English language has a rich vocabulary to refer to polite and courteous behaviour. This is true not only for Present-day English but also for older stages of the language. The Historical Thesaurus of the Oxford English Dictionary

1 My thanks go to the organizers of the Medieval English Studies Symposium in Poznań for inviting me to deliver this paper as a plenary talk at their 2012 meeting. I also thank Daniela Landert, Joanna Kopaczyk, and Miriam Locher for very useful comments on a draft version of this paper. The usual disclaimers apply. 
lists 1704 expressions under the heading of "good behaviour" and within that 781 under the heading of "courtesy". A considerable number of these expressions are first attested in the Middle English period. Jucker et al.(2012) investigated the development of the semantic field of courtesy and politeness in the history of the English language, and they found that the Middle English period was particularly rich in new courtesy and politeness related vocabulary. They retrieved 67 terms from the Historical Thesaurus under the narrow headings "courtesy, n", "courteous, a" and "courteously, adv". 30 of these 67 expressions were first attested between 1150 and 1420 (Jucker, Taavitsainen \& Schneider 2012: section 3.2). A search for these terms and their spelling variants in the Helsinki Corpus revealed that the semantic field of courtesy and politeness must have been particularly important in the Middle English period. In the Early Modern English period these terms are attested significantly less frequently (Jucker, Taavitsainen \& Schneider 2012: section 3.4).

It appears, therefore, that Middle English is a very important period for the development of the English politeness vocabulary, and that it seems worthwhile to investigate manifestations of courtesy and politeness in the Middle English period. Many of the new terms of courtesy and politeness were imported from French, and it is likely - given the structure of society in England during the Middle English period - that patterns of behaviour were also borrowed from French.

In earlier publications I have argued that Middle English provides a bridge between Old English and Present-day English not only in terms of phonology, morphology, syntax, and vocabulary but also in terms of pragmatics and, in particular, in terms of courteous and polite behaviour (Jucker 2010, 2012a). Old English was the language of a society characterised by strict hierarchies, kinloyalty, and mutual obligation, but it was also a society that adopted the Christian values of caritas and humilitas, while face-based politeness strategies, indirectness, and non-imposition so typical of many varieties of Present-day English were much less important (see in particular Kohnen 2008). Under the influence of the French, Middle English adopted the concept of "curteisie”, 'courteous behaviour' or 'behaviour that is appropriate at court', which, ultimately, was instrumental in the development of later forms of politeness (see in particular Fitzmaurice 1998; Locher 2008).

In the present article I would like to focus on the manifestations of courtesy and politeness in one particular late fourteenth-century Middle English alliterative romance, Sir Gawain and the Green Knight. In particular I want to show how a discursive approach to politeness can be applied to a medieval, fictional text. It is the Arthurian story of a beheading game, but it is also a story of honour and chivalry and as such it depicts courtly behaviour and, in fact, in many scenes problematizes the dilemmas of observing the multiple requirements of 
appropriate behaviour at court. I will focus my analysis on the three bedroom scenes of Sir Gawain and the Green Knight, in which Sir Gawain is tempted by the lady of the house and faces the dilemma of either staying courteous towards the lady or loyal to his host, Bertilak de Hautdesert, and to his knightly ideals. Thus it gives us a fictional and fairy-tale characterisation of courtly values at the end of the fourteenth century.

\section{Approaches to politeness}

Many politeness approaches to fictional texts have been modelled on Brown \& Levinson's (1987) work based on the concept of face and on positive and negative politeness strategies. Brown \& Gilman (1989), Kopytko (1993, 1995), and Bouchara (2009), for instance, applied it to Shakespeare's work. They tried to identify the various positive and negative strategies proposed by Brown \& Levinson in a selection of the plays. On this basis, Brown \& Gilman test the accuracy of Brown \& Levinson's formula that accounts for the weightiness of a face threat. Kopytko provides statistics for the frequencies of the individual strategies and he concludes that the world of Shakespeare's plays is largely a positive politeness culture, which he contrasts to the largely negative politeness culture of Present-day English (Kopytko 1995: 532). And Bouchara (2009) basically provides a faithful replication of Brown \& Gilman's work with an extension to some additional plays.

However, politeness theory has moved a long way since Brown \& Levinson's seminal work. A great number of new approaches have been proposed and a considerable amount of criticism has been levelled at Brown \& Levinson's approach to politeness. There is no room to give a full outline of this criticism and of the theoretical developments since then (see e.g., Eelen 2001; Watts 2005; Locher \& Watts 2005; Culpeper 2011; Locher 2012), but I would like to point out the key issues that are relevant for my analysis of Sir Gawain and the Green Knight.

Brown \& Levinson's (1987) approach to politeness focused on trouble elimination. Their positive and negative politeness strategies were designed to counteract face-threatening situations. If a speaker wants to get something done by the addressee, for instance, he or she has to impose and thus threaten the addressee's negative face, and in order to do this, according to Brown \& Levinson, he or she will employ an appropriate politeness strategy. Their categories are static. A certain linguistic form is mapped directly to a certain politeness value. Indirect formulations, for instance, are considered to be particularly polite.

More recent approaches to politeness extend this perspective in several directions. First, politeness is no longer seen as marked behaviour designed to solve interactional problems. Speakers constantly choose socially and situationally ap- 
propriate forms of language even without any face-threats. Watts $(1989,1992)$ introduced the term "politic behaviour" to refer to such forms of situationally appropriate forms of language use (see also Watts 2003: 21). Ide (1989: 230) proposed the term "discernment politeness" as a close equivalent of the Japanese wakimae to refer to behaviour that shows "verbally and non-verbally one's sense of place or role in a given situation according to social conventions". On the background of Japanese, she focuses in particular on those "linguistic forms or expressions in which the distinction between the ranks or the roles of the speaker, the referent and the addressee are systematically encoded" (Ide 1989: 230). In English, such encodings typically occur in the choice of terms of address, both nominal and, historically, in the pronominal choice of ye and thou. Thus, politeness is seen in a larger context of various forms of behaviour that range from unmarked, appropriate behaviour across marked, polite behaviour to various forms of inappropriate, impolite or rude behaviour (Watts 2005: xliii).

Second, politeness values are no longer mapped directly onto linguistic forms, they are discursively negotiated. A particular linguistic form may be polite in one situation and inappropriate or even impolite in another situation. Excessively indirect and hedged requests, for instance, may come across as courteous and highly polite in a very formal situation with an addressee who is in a much higher social position than the requester and they may come across as sarcastic and impolite from a boss to his or her employee. Thus the politeness researcher needs to pay attention to the discursive struggle of the interactants, the way they either accept formulations as appropriate or enter into an explicit discourse about appropriateness of specific utterances.

And third, a distinction needs to be made between first order politeness and second order politeness, also called politeness ${ }_{1}$ and politeness 2 . Politeness $s_{1}$ refers to the folk notion of politeness, to the fuzzy range of behaviours for which a speech community regularly uses the expression "politeness". Politeness 2 , on the other hand, refers to the use of the same expression as a technical term with a precise definition. Scholarly research into politeness can either focus on first order politeness or on second order politeness. Early politeness researchers, such as Brown \& Levinson (1987) and others following in their tradition, investigated a particular range of behaviours for which they used their own (second order) definition of what politeness is while more recent approaches often take their starting point in the politeness vocabulary of a particular speech community.

We consider it important to take native speaker assessments of politeness seriously and to make them the basis of a discursive, data-driven, bottom-up approach to politeness. The discursive dispute over such terms in instances of social practice should represent the locus of attention for politeness research. By discursive dispute we do not mean real instances of disagreement amongst members of 
a community of practice over the terms "polite", "impolite", etc. but rather the discursive structuring and reproduction of forms of behavior and their potential assessments (...) by individual participants. (Locher \& Watts 2005: 16)

In the following analysis of Sir Gawain and the Green Knight I will try to show how such a discursive approach can be applied to historical and to fictional data.

\section{Sir Gawain and the Green Knight}

The late fourteenth-century verse narrative Sir Gawain and the Green Knight tells the Arthurian story of a beheading game. Sir Gawain, one of King Arthur's knights, accepts the challenge from the Green Knight for an exchange of blows. Gawain can strike him with his axe if he is prepared to accept a blow in return in one year's time. Gawain strikes off the Green Knight's head, but in true fairy-tale fashion, the Green Knight picks up his head and, before he leaves, reminds Gawain to remember the appointment. After a long quest for the place of the encounter, Sir Gawain seeks refuge in Sir Bertilak de Hautdesert's castle. Sir Bertilak assures him that he can meet the Green Knight not far from the castle so he can rest in the castle for the remaining three days before the appointment. For the three days Gawain stays in the castle. Meanwhile Sir Bertilak goes hunting after having proposed a playful bargain with Gawain. In the evening they will exchange their winnings of the day. While Sir Bertilak is away, Sir Gawain is visited by the lady of the house in his bedchamber, where she tries to seduce him. However, Sir Gawain resists her seductive efforts. On the first day they exchange only one single kiss. In the evening, Sir Bertilak brings home a deer, which he presents to Sir Gawain. In return he receives a kiss from Gawain but Gawain does not reveal how he won the kiss, because that was not part of the bargain. On the second day, the lady continues her seductive efforts, and this time she exchanges two kisses with Gawain, who, in the evening, trades them for a boar. On the third day, finally, the lady redoubles her efforts once again but ultimately accepts defeat, except that in addition to now three kisses she also gives Sir Gawain a girdle of green and gold silk, which, as she assures him, will protect his life if he keeps it secret. In the evening, Sir Gawain trades the three kisses for a fox, but he conceals the girdle.

The narrative in general is an account of a serious test of Sir Gawain's chivalry, loyalty, and honour. First of all, having accepted the Green Knight's challenge, he is faced with a serious dilemma. If he backs out, he loses his honour, and if he does not, he is certain he will lose his life. And within this test he is faced with an almost equally serious dilemma, the lady's seductive advances. If he gives in to her seduction, he loses his honour, and if he does not, he is discourteous towards his hostess. 
His knightly honor is forfeit if he backs out [of the encounter with the Green Kinght]; his life, so far as he knows, is forfeit if he does not. But despite this dilemma, he must attend to the lady. He cannot, in all courtesy, refuse her request for dalliance; and yet, out of loyalty to his host he cannot really dally either. (Evans 1967: 42)

In the end he passes both tests, or at least almost. He resists the lady's temptation and dutifully relinquishes the kisses he has received from her, and he does not shy away from the renewed encounter with the Green Knight. He only fails to the extent that he has not revealed the girdle. As a result he receives only a very mild punishment at the hands of the Green Knight. The first two blows do not strike him and the third blow, on account of the girdle, inflicts only a minor wound.

The three bedroom scenes are the focal points of his trial. The lady approaches him when he is in a vulnerable position. He is still in bed, presumably undressed under his covers and, therefore, unable to get up and address the lady in an appropriate posture. Moreover he is alone with the lady of the castle. Her husband with his retinue has left for the day and will not return before the evening. And the door to the bedroom is locked. This is certainly not a situation prescribed by courtly formality. In this situation it seems paramount but at the same time exceedingly problematic to uphold the prescribed formality and courtesy of interaction.

\section{Analysis}

In the following analysis I will focus on several different aspects of courtesy and politeness in the three seduction scenes of Sir Gawain and the Green Knight. First I will focus on the discourse of politeness, i.e., on scenes in the interaction between Sir Gawain and the lady, where the two explicitly talk about the rules of courtly behaviour. I will then have a closer look at the nominal and pronominal terms of address that the two interactants use for each other. And finally I will look at some of the requests that they issue. In a traditional Brown \& Levinson type of approach, requests are seen as face-threatening acts that threaten the negative face of the addressee by encroaching on his or her freedom from imposition. In a discursive approach it will be important to try to uncover the contextual values of particular forms of behaviour at the specific points in the interaction at which they occur.

\subsection{The discourse of politeness}

The question of appropriate behaviour is one of the main themes that go through the three encounters between Sir Gawain and the lady. On the first morning Sir Gawain wakes up and becomes aware that the lady of the house has entered his 
room. The narrator describes how Gawain pretends to still be asleep and how he deliberates his options in this precarious situation. Should he continue his pretence of being asleep or should he wake up and address the lady? He decides in his thoughts, More semly hit were/ To aspye wyth my spelle in space quat ho wolde (SGGK III, 48, lines 1198-1199) ${ }^{2}$ ('More seemly 'twould be/ in due course with question to enquire what she wishes'), and thus the narrator immediately introduces the issue of "seemly" behaviour.

The lady teases him for his carelessness in letting somebody approach him in his sleep, and she refuses his request to let him get up and get dressed. And within the first few lines she touches on the topic of courtesy. She praises Sir Gawain for his courtesy and for his reputation to be courteous (line 1229). Thus, she focuses on his dilemma right from the start. If he is courteous, he has to serve her and fulfil her wishes, but at the same time such a course of action is unthinkable.

(1) For I wene wel, iwysse, Sir Wowen ze are, pat alle pe worlde worchipez quere-so ze ride;

Your honour, your hendelayk is hendely praysed With lordez, with ladyes, with alle pat lyf bere.

And now ze ar here, iwysse, and we bot oure one; (SGGK III, 49, lines 1226-1230)

For I wot well indeed that Sir Wawain you are, to whom all men pay homage wherever you ride; your honour, your courtesy, by the courteous is praised, by lords, by ladies, by all living people.

And right here you now are, and we all by ourselves;

She praises him not for his deeds, but for his reputation, his honour, and what she calls his "hendelayk" 'courtliness, courtesy'. She immediately adds that they are now alone. In the continuation of the passage reproduced in (1), she points out that her husband and his huntsmen are away hunting, everybody else is still in bed and the door to his bedroom is securely locked. But Gawain does not fall for the temptation. He disclaims being worth so much reputation, and praises the lady of the house for her own honour and reputation. The narrator summarises a long interaction by saying that they continued to talk of many matters until late into the morning. Finally, the lady prepares to take her leave,

2 The original text follows the edition by Tolkien \& Gordon (1925), second edition edited by Davis (1967); the translation is taken from Tolkien's translation (ed. by Christopher Tolkien 1975). The reference indicates the part of the manuscript, the stanza (numbers taken from the translation) and the line numbers (taken from the Davis edition). 
and again she puts him in a dilemma. Once again, she reminds him of his reputation of courtesy, but according to her, courtesy towards a lady should have induced him to crave a kiss from her during such a long interaction.

(2) Denne ho gef hym god day, and wyth a glent lazed,

And as ho stod, ho stonyed hym wyth ful stor wordez:

'Now he pat spedez vche speech pis disport zelde yow!

Bot pat ze be Gawan, hit gotz in mynde.'

'Querfore?'quop be freke, and freschly he askez,

Ferde lest he hade fayled in fourme of his castes;

Bot pe burde hym blessed, and 'Bi pis skyl' sayde:

'So god as Gawayn gaynly is halden,

And cortaysye is closed so clene in hymseluen,

Couth not lyztly haf lenged so long wyth a lady,

Bot he had craued a cosse, bi his courtaysye,

Bi sum towch of summe tryfle at sum talez ende.'

pen quop Wowen: 'Iwysse, worpe as yow lykez;

I schal kysse at your comaundement, as a kny3t fallez,

And fire, lest he displese yow, so plede hit no more.'

Ho comes nerre with pat, and cachez hym in armez,

Loutez luflych adoun and pe leude kyssez.

Pay comly bykennen to Kryst ayper oper;

Ho dos hir forth at pe dore without dyn more;

(SGGK III, 52, 1290-1308)

Then she gave him 'good day', and with a glance she laughed, and as she stood she astonished him with the strength of her words:

'Now He that prospers all speech for this disport repay you!

But that you should be Gawain, it gives me much thought.'

'Why so?', then eagerly the knight asked her,

afraid that he had failed in the form of his converse.

But 'God bless you! For this reason', blithely she answered,

'that one so good as Gawain the gracious is held,

who all the compass of courtesy includes in his person

so long with a lady could hardly have lingered

without craving a kiss, as a courteous knight,

by some tactful turn that their talk led to.'

Then said Wawain, 'Very well, as you wish be it done.

I will kiss at your command, as becometh a knight,

and more, lest he displease you, so plead it no longer.'

She came near thereupon and caught him in her arms,

and down daintily bending dearly she kissed him.

They courteously commended each other to Christ.

Without more ado through the door she withdrew and departed,

Thus, the laws of courtesy impose contradictory demands on Gawain. The lady explicitly refers to courtesy that should have been a motivation for Sir Gawain to give in to her advances. Gawain's restraint is interpreted as discourteous, 
perhaps even an insult towards her, the lady of the house. At the same time, Gawain is aware that giving in to her temptations would be an extreme act of discourteousness and disloyalty towards his host, Sir Bertilak de Hautdesert. On this first morning he emerges unscathed. He has exchanged a kiss with the lady of the house, but in the evening he will pass on the kiss to Sir Bertilak as part of their bargain to exchange the winnings of the day.

On the second morning, the lady visits him again and redoubles her efforts of seducing him. Again she sits down by his side on his bed. And this time she refers even more explicitly to the rules of courteous behaviour, the customs of the gentle (of companye pe costez). Tolkien here translates companye as 'the gentle', and glosses it as '(polite) society' (Davis 1967: 172).

(3) 'Sir, zif ze be Wawen, wonder me bynkkez,

Wyзe pat is so wel wrast alway to god,

And connez not of compaynye pe costez vndertake,

And if mon kennes yow hom to knowe, ze kest hom of your mynde;

pou hatz forzeten zederly pat zisterday I taztte

Bi alder-truest token of talk pat I cowpe.'

'What is pat?' quop pe wyghe, 'Iwysse I wot neuer;

If hit be soothe pat ze breue, pe blame is myn awen.'

' 'Zet I kende yow of kyssyng,' quop pe clere penne,

'Quere-so countenaunce is coupe quikly to clayme;

pat bicumes vche a kny3t pat cortaysy vses.'

(SGGK III, 59, 1481-1491)

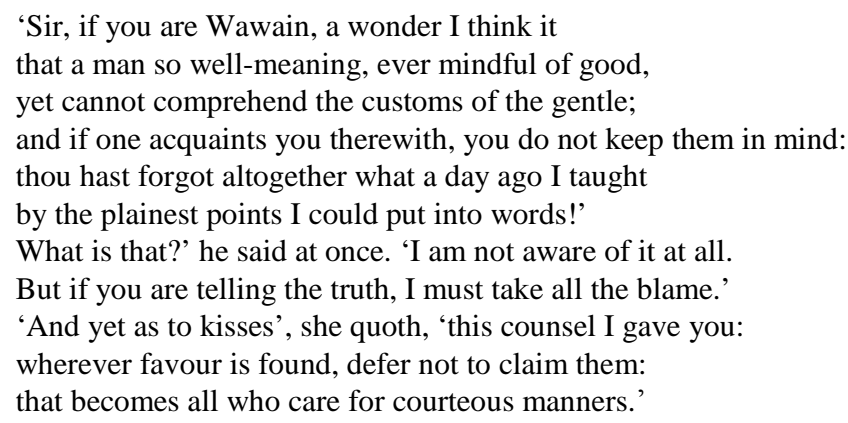

If he is well-meaning and concerned about being good, she argues, he should follow the customs of polite society and should not refuse a favour that is offered to him. Everybody who cares for courteous manners (bat cortaysy vses) should accept such favours. This increases the pressure on Gawain, who now must even more explicitly break what the lady presents as the rules of courtesy. He argues that he did not dare to accept the favour because he feared that he would be rejected. But the lady does not accept this argument. She points out that he would be strong enough to take a favour if anybody were so 
ill-bred to refuse him (zif any were so vilanous pat yow devaye wolde) (SGGK III, 59, 1497), insinuating that he could have kissed her even against her will, had he so wished, but that she would not have been so discourteous as to refuse him. He protests that where he comes from people do not take favours by force but only exchange them out of their own free will, but he is ready (at your comaundement) (SGGK III, 59, 1501) to kiss her whenever she wishes. So, they kiss again.

But the lady is not yet satisfied. She again refers to his breeding, his chivalry, and the famous art of knightly love, and wonders why he has not talked to her about art of courtly love.

(4) 'And yow wrathed not perwyth, what were be skylle

pat so zong and so zepe as ze at pis tyme,

So cortayse, so knyztyly, as ze ar knowen oute -

And of alle cheualry to chose, pe chef byng alosed

Is be lel layk of luf, pe lettrure of armes;

(SGGK III, 60, 1509-1513)

\footnotetext{
'if you would not mind my asking, what is the meaning of this: that one so young as are you in years, and so gay,

by renown so well known for knighthood and breeding, while of all chivalry the choice, the chief thing of praise, is the loyal practice of love: very lore of knighthood -
}

So, once again she challenges him to behave according to the code of chivalry and courtly love, but he is well aware that if he were to do so, he would violate exactly this code of chivalry and courtly love. On the surface, he is in a double bind in which he can only lose. He breaks the code both if he gives in to her wooing and if he withstands it. But on closer inspection, the choice is between the code of chivalry and the code of courtesy. The code of chivalry requires him to remain true to his principles, loyal to his host and faithful to the Arthurian ideals of knightly behaviour. The code of courtesy that the lady insists upon, on the other hand, requires him to accept her favours and to yield to her desires. $\mathrm{He}$ is caught between two paradigmatic codes (Burlin 1995: 12-13). Before the lady leaves, she kisses him a second time, and again, Sir Gawain retains his innocence by exchanging the two kisses of the second encounter with Sir Bertilak's winnings of the day, a boar.

On the third day, the lady greets him with a kiss, and starts to press him even harder.

(5) For pat prynces of pris depressed hym so pikke,

Nurned hym so neze pe pred, pat nede hym bihoued

Oper lach per hir luf, oper lodly refuse. 


\begin{abstract}
He cared for his cortaysye, lest crapayn he were, And more for his meschef 3 if he schulde make synne, And be traytor to pat tolke pat pat telde a3t.

(Sir Gawain and the Green Knight III, 71, 1770-1775)

For she, queenly and peerless, pressed him so closely, led him so near the line, that at last he must needs either refuse her with offence or her favours there take. He cared for his courtesy, lest a caitiff he proved, yet more for his sad case, if he should sin commit and to the owner of the house, to his host, be a traitor.
\end{abstract}

The narrator describes Gawain's dilemma in very clear terms. On the one hand, there are the obligations of courtesy according to which he cannot refuse the requests of the lady of the house, and on the other his own innocence, which makes it impossible to betray his host. He cannot observe both codes, he must decide whether to lach per hir luf 'take her favours' or whether to lodly refuse 'refuse with offence'. At this point she suspects that he must love another lady. When he denies, she is finally defeated. If he refuses her without being tied to some other lady, there can be no hope for her. They kiss again, and she prepares to leave, but not before having asked him for a love token. He refuses on the grounds that he does not have anything that would be sufficiently worthy of her. So she offers him a precious ring, but he refuses again. When she offers him a magic girdle that would protect him in the encounter with the Green Knight, he accepts the gift. She urges him to keep the gift a secret, and leaves him with the third kiss of the day.

\title{
4.2. The power dynamics of naming
}

Nominal and pronominal terms of address and their pragmatic impact have received a considerable amount of attention recently. U. Busse (2002, 2003) and B. Busse (2006) have provided extensive studies focussing on terms of address in the work by William Shakespeare (see also U. Busse \& B. Busse 2010; Jucker 2012b). Honegger (2003) has argued that nominal and pronominal terms of address must be seen as a wider system of interaction between characters of narratives. This system, which he calls "adversion”, also includes non-verbal elements, such as gestures, gaze, facial expressions, posture, and so on.

De Roo (1997) has pointed out how names exert power, and how an unidentified character has power over an identified character. This is one of the driving forces in Sir Gawain and the Green Knight, in which the identities of the main characters (the Green Knight, Sir Bertilak de Hautdesert, Morgan Le Fay) are only revealed at the very end of the poem. In this context it is also significant that the lady who visits Sir Gawain in his chamber is never named. 
Her anonymity does nothing to diminish the possibilities she represents from romance tradition on her initial entrance into the bedroom - a woman seduced by the knight's reputation; a lady in distress; a seductress; the wife of the "Generous Host;” a Potiphar's wife; an agent of the devil. Isn't the power of her actions augmented by these multiple possibilities of the unidentified? (De Roo 1997: 242, italics original)

Table 1 gives an overview of the nominal terms of address that the lady and Sir Gawain use for each other in the three bedroom scenes. They also include some adjectives that are used nominally as terms of address.

Table 1. Nominal terms of address between Sir Gawain and Lady Bertilak

\begin{tabular}{l|l|l}
\hline & The lady to Sir Gawain & Sir Gawain to the lady \\
\hline First encounter & Sir Gawayn & gay \\
& beau sir & lady louely \\
& my kny3t & Madame \\
& Sir Wowen & my souerayn \\
& Sir Gawayn & \\
& hende & \\
& kny3t & \\
\hline Gawan & me dere \\
\hline Second encounter & Sir & lade \\
\hline Third encounter & mon & my gay \\
& dere & \\
\hline
\end{tabular}

In the very first line that the lady addresses to Sir Gawain, she addresses him with his name (“God moroun, Sir Gawayn,' sayde pat gay lady," SGGK, 1208). This may seem trivial as she obviously knows who he is, but it is also significant. In the sense of De Roo (1997) she exerts power over him. It conforms to the fairy-tale reality where figures, such as Rumpelstiltskin, lose their power as soon as they are named. She continues to address him with his name in various spelling variations throughout the encounter. In an alliterative poem, such as Sir Gawain and the Green Knight, the choice of terms of address is presumably not only based on considerations of the semantic and pragmatic impact of a particular name, but also on the formal constraints of alliterative form. A particular term must conform to the requirements of a particular poetic line (see Honegger 2005), and this may account for some of the variability, but the nominal terms that are not his name, beau sir, hende 'courteous, gracious (one)', and knyzt, indicate how she frames him. Through these names she reminds him of his duties as a courteous knight and thus increases the pressure on him not to distress her by opposing her wishes. 
Sir Gawain's terms in the first encounter are somewhat less varied. He addresses her as gay 'fair lady', lady louely, Madame and souerayn 'liege lady', and, thereby, stresses her social position and the fact that he is obliged to serve her.

In the second encounter only two nominal terms of address are used. The lady addresses Sir Gawain as Sir, and he addresses her as me dere. In the third encounter, finally, the lady uses only mon and dere. In the opening line of their interaction when she greets him, she calls him mon (extract (6)), and when she asks him for a love token, she calls him dere (extract (7)).

(6) 'A! mon, how may pou slepe,

bis morning is so clere?'

(SGGK III, 69, 1746-1747)

'Ah! man, how canst thou sleep,

the morning is so clear!'

(7) 'Now, dere, at pis departyng do me pis ese,

Gif me sumquat of py gifte, pi gloue if hit were,

pat I may mynne on pe, mon, my mournyng to lassen.'

(SGGK III, 72, 1798-1800)

'Now, my dear, at this parting do me this pleasure,
give me something as thy gift, thy glove it might be,
that I may remember thee, dear man, my mourning to lessen.'

She no longer addresses him with his name as in the first encounter. Her strategy has changed. In the first encounter, she used his name and nominal terms that stressed chivalry. At this point she uses very plain terms. She no longer appeals to his chivalry but merely to his gender as a man and to her feelings for him. It is also significant that at these two points she does not use the expected pronoun ye for him but addresses him with thou.

In the thirteenth century, under the influence of French, English started to use two different pronouns to address a single person. In addition to the second person singular pronoun thou, the second person plural ye came to be used in some situations for single addressees. Until about the seventeenth century, English kept the choice between the two pronouns, which are traditionally abbreviated as $\mathrm{T}$ and $\mathrm{Y}$ (or on the analogy of French $\mathrm{T}$ and $\mathrm{V}$ ). But after that time $\mathrm{Y}$ became the standard and $\mathrm{T}$ remained only in a few specialized contexts, such as some religious uses and a few local dialects (for overviews see Jucker \& Taavitsainen 2003; Mazzon 2010).

Most studies of the T-Y distinction in Middle English focus on Chaucer's work, and, in fact, mostly on the Canterbury Tales (e.g., Wilcockson 1980; Mazzon 2000; Burnley 1983, 2003; Knappe \& Schumann 2006; Jucker 2006). Skeat summarises the rules for the use of $\mathrm{Y}$ and $\mathrm{T}$ as follows: 
Thou is the language of the lord to a servant, of an equal to an equal, and expresses also companionship, love, permission, defiance, scorn, threatening; whilst $y e$ is the language of a servant to a lord, and of compliment, and further expresses honour, submission, or entreaty. (Skeat 1894: V, 175)

De Roo (1997) provides a similar analysis for Sir Gawain and the Green Knight. He argues that mutual Y between aristocrats conveys "respect through the solidarity of mutual formality" (De Roo 1997: 234) and he explicitly mentions the dyad of Sir Gawain and the lady. Mutual reciprocal T between aristocrats conveys "the solidarity of mutual intimacy" (De Roo 1997: 233), and for this usage he also lists the dyad of Sir Gawain and the lady, although he notes that this occurs only rarely. However, I think it is more adequate to argue that they never exchange reciprocal $\mathrm{T}$, even though they both use $\mathrm{T}$ for the other on a few occasions, the lady on several occasions in all three encounters and Sir Gawain only once in the third encounter, as I will describe in more detail below.

The situation of pronoun usage in Middle English is more complex. Speakers often switch from one pronoun to the other and back while still addressing the same interlocutor. The choice appears to be flexible.

\footnotetext{
Although general hints on the factors governing the choice of ye or thou can be given, it is important to realise that no unbreakable rules exist. The choice between ye and thou when addressing a single individual is not a grammatical one, but a stylistic one governed not only by institutionalised forms of social structure, but also by transient emotions and attitudes arising from a relationship (Burnley 1983: 19).
}

However, I have argued in earlier publications (Jucker 2006, 2010) that the choice is not merely a stylistic one. Moreover, it differs considerably from present-day languages which still make a similar distinction between two different pronouns of address, such as French, German or Italian. In Middle English the choice of $\mathrm{T}$ or $\mathrm{Y}$ depends on the situational power at a given moment in an interaction, where the situational power is a conglomerate of the respective social status of the interactants, their role-relationship and the dynamics of the conversation. As a result, one speaker may start out addressing an interactant with $\mathrm{Y}$ and then - through a turn in the conversation - may gain the upper hand and as a result switch to $\mathrm{T}$ both as a reflection and a signal of his or her momentary power over the addressee. And later in the conversation - when the show of power is no longer necessary - the usage may well switch back to $\mathrm{Y}$ again. This differs from related modern usages, where the choice of $\mathrm{T}$ or $\mathrm{V}$ (for French vous) remain relatively stable for each dyad of two interlocutors. Modern readers may be tempted, on the basis of modern usage in languages that still have 
the distinction, to conceive of the choice between $\mathrm{T}$ and $\mathrm{Y}$ as a distinction of intimacy versus distance, but I will show below that in a courtly setting intimacy does not call for the use of T. On the contrary, $\mathrm{Y}$ is more appropriate because it signals respect and possibly submission while $\mathrm{T}$ signals dominance.

Between Sir Gawain and the lady the use of Y is the default in this courtly setting, and both speakers predominantly adhere to this choice. However, it is interesting that they do not always use the expected pronoun. The lady uses $\mathrm{T}$ eight times against 42 instances of $\mathrm{Y}$. Gawain uses T only once against 35 uses of the expected Y (see Table 2).

Table 2. Pronominal terms of address between Sir Gawain and Lady Bertilak

\begin{tabular}{l|lrr|lr}
\hline & \multicolumn{2}{l}{$\begin{array}{l}\text { Lady Bertilak to Sir } \\
\text { Gawain }\end{array}$} & \multicolumn{2}{l}{$\begin{array}{l}\text { Sir Gawain to Lady Ber- } \\
\text { tilak }\end{array}$} \\
\hline First encounter & T & 3 & & T & - \\
& Y & 17 & & Y & 19 \\
\hline Second encounter & T & 1 & & T & - \\
& Y & 18 & & Y & 13 \\
\hline Third encounter & T & 4 & & T & 1 \\
& Y & 7 & & Y & 3 \\
\hline
\end{tabular}

It might be hypothesized that these deviations indicate a closer intimacy. On the lady's side it might be an insistence on intimacy even where it is unseemly and in the case of Sir Gawain one might speculate that in the third encounter he is on the brink of giving in to the lady's advances and, therefore, slips into the more intimate $\mathrm{T}$. But a closer reading indicates that respect and dominance are the guiding principles for the choice of $\mathrm{Y}$ and $\mathrm{T}$ respectively.

At the beginning of their first encounter, both the knight and the lady use the expected $\mathrm{Y}$ pronoun. In spite of the unusual setting of the bedroom they address each other with respect and courtesy. The lady first gives a few hints that her husband is away and then explicitly invites him to take advantage of the situation, and she uses Y throughout this first offer. When Gawain shows reluctance, she increases her enticement by pointing out that he is actually in her power, and at this point she switches to T. Other ladies would be happy to have him in their power in the same way as she has him now.

(8) Bot hit ar ladyes innoze pat leuer wer nowpe Haf pe, hende, in hor holde, as I pe habbe here, (SGGK III, 50, 1251-1252)

But there are ladies in number who liever would now have thee in their hold, sir, as I have thee here, 
She continues with $\mathrm{T}$ a little later when she tells him that if she had to choose a husband she would prefer him before all others. Immediately afterwards she reduces her insistence, becomes more playful again and switches back to $\mathrm{Y}$ to steal the first kiss from him.

In the second encounter the lady again greets Gawain with $\mathrm{Y}$, but she only takes a few lines to switch to $\mathrm{T}$ when she playfully reproaches him for having forgotten the lesson of the previous day.

(9) Dou hatz forzeten zederly pat zisterday I taztte

Bi alder-truest token of talk pat I cowpe.'

(SGGK III, 59, 1485-6)

thou hast forgot altogether what a day ago I taught

by the plainest points I could put into words!'

Gawain is intimidated by the reproach and perhaps also by her choice of pronoun. He does not know why he is - playfully - chided by the lady of the house. She switches back to $\mathrm{Y}$ and reminds him that he should not refuse favours offered to him. She points out that he is so strong that he could even have taken the favour by force, and she certainly would not have refused it. She wants to learn from him the art of courtly love. Thus she only uses $\mathrm{T}$ for him when she reproaches him but not in her more submissive wooing strategy.

In the third encounter, finally, there are more switches. She immediately addresses him with $\mathrm{T}$, and this time reproaches him for still sleeping.

(10) 'A! mon, how may pou slepe,

bis morning is so clere?'

(SGGK III, 69, 1746-1747)

'Ah! man, how canst thou sleep, the morning is so clear!'

And before he is fully awake she kisses him for the first time during this third encounter. When she tells him how wounded she is in her heart and when she asks him whether he serves another lady, she adheres to Y. It is only at the point where she realizes that he refuses her without serving another lady that she accepts defeat, but she requests a love token from him, and for this she switches back to $\mathrm{T}$ and uses it three times in two lines (by gifte, pi gloue, on pe) to increase the effect and the insistence of the request.

(11) 'Now, dere, at pis departyng do me pis ese,

Gif me sumquat of by gifte, pi gloue if hit were,

bat I may mynne on pe, mon, my mournyng to lassen.'

(SGGK III, 72, 1798-1800) 


\begin{abstract}
'Now, my dear, at this parting do me this pleasure, give me something as thy gift, thy glove it might be, that I may remember thee, dear man, my mourning to lessen.'
\end{abstract}

For the remaining lines in which the lady first offers a precious ring and then the protective girdle as her love tokens to him she returns to the use of Y.

Sir Gawain only once uses a $\mathrm{T}$ pronoun for the lady, otherwise he always addresses her by $\mathrm{Y}$. The one instance occurs in the third encounter, when Gawain refuses to give her a love token.

(12) 'Now iwysse,'quop pat wyze, 'I wolde I hade here pe leuest ping for by luf pat I in londe welde, For ze haf deserued, for sope, sellyly ofte More rewarde bi resoun pen I reche my3t; Bot to dele yow for drurye pat dawed bot neked, Hit is not your honour to haf at pis tyme A gloue for a garysoun of Gawaynez giftez, (SGGK III, 72, 1801-7)

\footnotetext{
'Now on my word,' then said he, 'I wish I had here the loveliest thing for thy delight that in my land I possess; for worthily have you earned wondrously often more reward by rights than within my reach would now be, save to allot you as love-token thing of little value. Beneath your honour it is to have here and now a glove for a guerdon as the gift of Sir Gawain:
}

At this point, the lady has relinquished her wooing, and he has survived the precarious situation she has put him in - as far as he is aware at this point unscathed. He has remained both courteous towards her and true to his ideals of chivalry. He has no love token to offer her, in spite of his wish that he had something for by luf 'for thy delight', and with this choice of pronoun he both asserts his momentary interactional dominance and - by using by instead of the more respectful your - depreciates her feelings for him. To please her delight apparently does not deserve the pronoun of respect. But in the following utterances, he immediately switches back to the courtly courtesy of using the expected $\mathrm{Y}$ to the lady of the house. 


\subsection{Requests}

In terms of traditional politeness theory, requests are face-threatening acts because they threaten the addressee's negative face. They are attacks on his or her wish to remain free from impositions. In a discursive approach more attention is paid to situational differences. Speech acts are often ambiguous in terms of their illocutionary force. An assessment of the addressee's behaviour can on occasions be understood either as a compliment, as criticism or even an ironic insult. And a statement about the addressee's future actions might be anything from a suggestion, to an entreaty, a request or a command. In each case, the speaker may have clear intentions as to the illocutionary force of the utterance but choose a formulation that is to some extent unspecific, or the speaker may intentionally try to leave a range of interpretations to his or her utterance. Such interpretations are often the topic of discursive negotiations ("Is this a compliment?”). As we will see, the lady and Sir Gawain also engage in such negotiations, albeit less explicitly.

In the following I will focus on three requests which differ in the seriousness of the imposition they put on the addressee. In the first encounter, at the point when the lady has already taken her leave for the day, she asks for a kiss but she does this in a very indirect way in the passage given in (13) (which was already discussed as extract (2) above).

(13) 'So god as Gawayn gaynly is halden,

And cortaysye is closed so clene in hymseluen,

Couth not lyztly haf lenged so long wyth a lady,

Bot he had craued a cosse, bi his courtaysye,

Bi sum towch of summe tryfle at sum talez ende.'

Den quop Wowen: 'Iwysse, worpe as yow lykez;

I schal kysse at your comaundement, as a kny3t fallez,

(SGGK III, 52, 1297-1304)

\footnotetext{
'that one so good as Gawain the gracious is held, who all the compass of courtesy includes in his person so long with a lady could hardly have lingered without craving a kiss, as a courteous knight, by some tactful turn that their talk led to.'

Then said Wawain, 'Very well, as you wish be it done. I will kiss at your command, as becometh a knight,
}

She expresses her astonishment at the fact that he has not tried to kiss her during their encounter. She hints that this would have been the expected behaviour from a knight in his position. But Gawain does not interpret this speech as a mere description of her feelings or an assertion of her assessment of how their conversation has gone. He clearly takes it as no less than a command: I schal 
kysse at your comaundement and he immediately proceeds to obey her orders. In this case, the illocutionary force of the lady's utterance is not encoded in the utterance. It is Gawain's reading of the utterance that turns it into a request or even a command. Lady Bertilak does not dispute this reading and (silently) accepts it. Thus they successfully negotiate the illocutionary force of her utterance, and they act accordingly.

Extract (14) is taken from the second encounter. The lady entreats Gawain to tell her the secrets of courtly love. She takes an entire stanza of 26 lines to issue and reinforce her request. She starts with some phrases that seem to resonate with Present-day English negative politeness strategies: I woled wyt at yow, wyze and And yow wrathed not perwyth, which Tolkien translates as 'I would learn from you, lord,' and 'if you would not mind my asking'. But she also adds what might be analysed as positive politeness. She again praises his courtesy, his chivalry and his reputation. At the very end of the stanza, however, she resorts to a bold on record strategy techez me of your wytte 'come, teach me of your wit'.

(14) 'I woled wyt at yow, wyze,' pat worpy per sayde, 'And yow wrathed not perwyth, what were be skylle pat so zong and so zepe as ze at pis tyme,

So cortayse, so kny3tyly, as ze ar knowen oute -

And of alle cheualry to chose, pe chef pyng alosed Is pe lel layk of luf, pe lettrure of armes;

(...)

Why! Ar ze lewed, pat alle pe los weldez?

Oper elles ze demen me to dille your dalyaunce to herken?

For schame!

I com hider sengel, and sitte

To lerne at yow sum game;

Dos, techez me of your wytte,

Whil my lorde is fro hame.'

(SGGK III, 60, 1508-1513, 1528-1534)

'I would learn from you, lord,' the lady then said,

'if you would not mind my asking, what is the meaning of this:

that one so young as are you in years, and so gay,

by renown so well known for knighthood and breeding,

while of all chivalry the choice, the chief thing to praise,

is the loyal practice of love: very lore of knighthood -

(...)

Why? Are you ignorant who all honour enjoy?

Or else you esteem me too stupid to understand your courtship?

But nay!

Here single I come and sit,

a pupil for your play;

come, teach me of your wit,

while my lord is far away.' 
The entire stanza is a long request for him to teach her the art of courtly love. It is veiled at the beginning and direct at the end. At the beginning it is reinforced with extensive praise for him and his knightly ideals. Towards the end it becomes more insistent by suggesting that his refusal to teach her can only mean that he thinks she would not be able to understand his courtship (to dille your dalyaunce to herken 'too stupid to understand your courtship'), and she again emphasises the fact that they are alone and her husband is far away.

In the third encounter, finally, the tone has changed. She accepts her defeat and requests one last kiss. This time she does not hedge her request: Kysse me now comly.

(15) 'Pat is a worde,'quop pat wy3t, 'pat worst is of alle, Bot I am swared for sope, pat sore me pinkkez.

Kysse me now comly, and I schal cach hepen,

I may bot mourne vpon molde, as may pat much louyes.'

Sykande ho sweze doun and semly hym kyssed,

And sipen ho seueres hym fro,

(SGGK III, 72, 1791-1795)

\footnotetext{
'Those words', said the woman, 'are the worst that could be. But I am answered indeed, and 'tis hard to endure. Kiss me now kindly, and I will quickly depart.

I may but mourn while I live as one that much is in love.'

Sighing she sank down, and sweetly she kissed him;

then soon she left his side,
}

At this point indirectness is no longer required. She requests a kiss with a direct imperative. In terms of Brown \& Levinson's (1987) approach, this would be a bold-on-record strategy without any use of positive or negative politeness. She presents her request almost like a deal: If you kiss me, I will no longer disturb you. And she adds a sentence how she will mourn for him for the rest of her life. It is also significant that the narrator does not make Gawain kiss the lady in response to her request, but she kisses him, before she prepares to leave. In actual fact, she does not leave yet, but asks for the exchange of love tokens, and the interaction continues for two more stanzas.

\section{Conclusion}

In the fourteenth century romance Sir Gawain and the Green Knight, courtesy in its etymologically sense of 'courtly behaviour' or 'courtly elegance and politeness of manners' (OED, “courtesy”, n.) is of essential importance. Sir Gawain is caught in the dilemma of having to choose between courteous behaviour towards the lady of the house and his loyalty to the code of chivalry which forces him to be loyal and true to his host, Sir Bertilak, and it seems impossible 
- both to him and to the reader - that he can escape unscathed. He almost succeeds, and his lapse is only a minor one. In the words of Burlin (1995: 12-13) "Gawain's lapse, then, results from being caught between two paradigmatic codes", i.e., the code of chivalry and the code of courtesy.

Thus, in the fairy-tale context of this romance, courtesy is a form of expected behaviour. But even in this highly regulated context, these expectations are not fixed in terms of specific linguistic forms that have to be used. The terms of courteous interaction are negotiable. Sir Gawain and the lady thematise the rules of courteous behaviour. The lady refers to Gawain's reputation and courteousness to lead him into accepting her advances, and he refers to the ideals of courteousness and chivalry to justify why he does not give in to her temptations. They both adapt their choice of nominal and pronominal terms of address to the developing interaction and in response to their elaborate and polished intercourse, and the lady chooses the appropriate linguistic means to put her requests to Gawain.

All these levels must be seen in their discursive context. Specific terms of address and specific forms of requests do not have fixed politeness values, but they are part of the discursive negotiations of the relationship between the interactants. Such an approach does not lend itself to any quantification, but it requires a detailed analysis of the minutiae of an interaction. In fact, in this article I have focused on just three short scenes within this romance. It would be interesting to expand the analysis to the interactions between the characters at the court of King Arthur or between Sir Gawain and his host/opponent in the shape of Sir Bertilak and the Green Knight. But I hope to have been able to show that a discursive approach can be usefully applied to a fictional text which is more than six hundred years old. The analysis reveals the skill with which the anonymous author of Sir Gawain and the Green Knight characterized both the characters and their verbal interaction.

\section{REFERENCES}

\section{PRIMARY SOURCES}

Skeat, Walter W. (ed.). 1894. Complete works of Geoffrey Chaucer. Oxford.

Tolkien, Christopher (ed.). 1975. Sir Gawain and the Green Knight, Pearl and Sir Orfeo. Translated by J. R. R. Tolkien. London: Allen \& Unwin. [2006] [Reprinted. Harper Collins]

Tolkien, J. R. R. \& E. V. Gordon (ed.). 1967. Sir Gawain and the Green Knight. 2nd edn. Revised by Norman Davis. Oxford: Clarendon Press. 


\section{SECONDARY SOURCES}

Bouchara, Abdelaziz. 2009. Politeness in Shakespeare: Applying Brown and Levinson's Politeness Theory to Shakespeare's comedies. Hamburg: Diplomica.

Brown, Roger \& Albert Gilman. 1989. Politeness theory and Shakespeare's four major tragedies. Language in Society 18(2). 159-212.

Brown, Penelope \& Stephen C. Levinson. 1987. Politeness. Some universals in language usage (Studies in Interactional Sociolinguistics 4). Cambridge: Cambridge University Press.

Burlin, Robert B. 1995. Middle English romance: The structure of the genre. The Chaucer Review 30(1). 1-14.

Burnley, David. 1983. A guide to Chaucer's language. London: Macmillan.

Burnley, David. 2003. The T/V pronouns in later Middle English literature. In Irma Taavitsainen \& Andreas H. Jucker (eds.), Diachronic perspectives on address term systems (Pragmatics \& Beyond New Series 107), 27-45. Amsterdam: John Benjamins.

Busse, Beatrix. 2006. Vocative constructions in the language of Shakespeare (Pragmatics \& Beyond New Series 150). Amsterdam/Philadelphia: John Benjamins.

Busse, Ulrich. 2002. Linguistic variation in the Shakespeare corpus. Morpho-syntactic variability of second person pronouns (Pragmatics \& Beyond New Series 106). Amsterdam: John Benjamins.

Busse, Ulrich. 2003. The co-occurrence of nominal and pronominal address forms in the Shakespeare corpus: Who says thou or you to whom? In Irma Taavitsainen \& Andreas H. Jucker (eds.), Diachronic perspectives on address term systems (Pragmatics \& Beyond New Series 107), 193-221. Amsterdam: John Benjamins.

Busse, Ulrich \& Beatrix Busse. 2010. Shakespeare. In Andreas H. Jucker \& Irma Taavitsainen (eds.), Historical pragmatics (Handbooks of Pragmatics 8), 247-281. Amsterdam: John Benjamins.

Culpeper, Jonathan. 2011. Politeness and impoliteness. In Gisle Andersen \& Karin Aijmer (eds.) 2011, Pragmatics of society (Handbooks of Pragmatics 5), 393-438. Berlin: de Gruyter.

De Roo, Harvey. 1997. What's in a name? Power dynamics in Sir Gawain and the Green Knight. The Chaucer Review 31(3). 232-255.

Evans, William W. 1967. Dramatic use of the second-person singular pronoun in Sir Gawain and the Green Knight. Studia Neophilologica 39(1). 38-45.

Eelen, Gino. 2001. A critique of politeness theories (Encounters 1). Manchester: St. Jerome.

Fitzmaurice, Susan. 1998. The commerce of language in the pursuit of politeness in eighteenthcentury England. English Studies 79(4). 309-328.

Honegger, Thomas. 2003. "And if ye wol nat so, my lady sweete, thanne preye I thee, [...].”: Forms of address in Chaucer's Knight's Tale. In Irma Taavitsainen \& Andreas H. Jucker (eds.), Diachronic perspectives on address term systems (Pragmatics \& Beyond New Series 107), 61-84. Amsterdam: John Benjamins.

Honegger, Thomas. 2005. 'wy3e welcum iwys to this place': And never mind the alliteration: An inquiry into the use of forms of address in two alliterative ME romances. In Nikolaus Ritt \& Herbert Schendl (eds.), Rethinking Middle English: Linguistic and literary approaches, 169-178. Frankfurt/Main: Peter Lang.

Ide, Sachiko. 1989. Formal forms and discernment: Two neglected aspects of linguistic politeness. Multilingua 8(2/3): 223-248.

Jucker, Andreas H. 2006. "Thou art so loothly and so oold also": The use of ye and thou in Chaucer's Canterbury Tales. Anglistik 17(2). 57-72. 
Jucker, Andreas H. 2010. "In curteisie was set ful muchel hir lest”: Politeness in Middle English. In Jonathan Culpeper \& Dániel Z. Kádár (eds.), Historical (im)politeness (Linguistic Insights 65), 175-200. Frankfurt/Main: Peter Lang.

Jucker, Andreas H. 2012a. Changes in politeness cultures. In Terttu Nevalainen \& Elizabeth Traugott (eds.), The Oxford handbook of the history of English, 422-433. New York: Oxford University Press.

Jucker, Andreas H. 2012b. "What's in a name?”: Names and terms of address in Shakespeare's Romeo and Juliet. In Sarah Chevalier and Thomas Honegger (eds.), Words, words, words: Philology and beyond. Festschrift for Andreas Fischer on the occasion of his 65th birthday, 77-97. Tübingen: Narr Francke Attempto.

Jucker, Andreas H. \& Irma Taavitsainen. 2003. Diachronic perspectives on address term systems: Introduction. In Irma Taavitsainen \& Andreas H. Jucker (eds.), Diachronic perspectives on address term systems (Pragmatics \& Beyond New Series 107), 1-25. Amsterdam: John Benjamins.

Jucker, Andreas H., Irma Taavitsainen \& Gerold Schneider. 2012. Semantic corpus trawling: Expressions of "courtesy" and "politeness" in the Helsinki Corpus. In Carla Suhr \& Irma Taavitsainen (eds.), Developing corpus methodology for historical pragmatics (Studies in Variation, Contacts and Change in English 11). Helsinki: Research Unit for Variation, Contacts and Change in English, http://www.helsinki.fi/varieng/journal/ volumes/11/prag/jucker_taavitsainen_schneider/

Knappe, Gabriele \& Michael Schümann. 2006. Thou and ye: A collocational-phraseological approach to pronoun change in Chaucer's Canterbury Tales. Studia Anglica Posnaniensia 42. 213-238.

Kohnen, Thomas. 2008. Linguistic politeness in Anglo-Saxon England? A study of Old English address terms. Journal of Historical Pragmatics 9(1). 140-158.

Kopytko, Roman. 1993. Polite discourse in Shakespeare’s English. Poznań: Wydawnictwo Naukowe Uniwersytetu im. Adama Mickiewicza w Poznaniu.

Kopytko, Roman. 1995. Linguistic politeness strategies in Shakespeare's plays. In Andreas H. Jucker (ed.), Historical pragmatics: Pragmatic developments in the history of English (Pragmatics \& Beyond New Series 35), 515-540. Amsterdam: John Benjamins.

Locher, Miriam A. 2008. The rise of prescriptive grammars on English in the 18th century. In Miriam Locher \& Jürg Strässler (eds.), English standards and norms in the language (Contributions to the Sociology of Language 95), 127-147. Berlin: Mouton de Gruyter.

Locher, Miriam. 2012. Politeness research from past to future, with a special focus on the discursive approach. In Lucía Fernandez Amaya, Maria de la O. Hernandez Lopez, Reyes Gomez Moron, Manuel Padilla Cruz, Manuel Mejias Borrero \& Mariana Relinque Barranca (eds.), New perspectives on (im)politeness and interpersonal communication, 1-22. Cambridge: Cambridge Scholars Publishing.

Locher, Miriam A. \& Richard J. Watts. 2005. Politeness theory and relational work. Journal of Politeness Research 1. 9-33.

Mazzon, Gabriella. 2000. Social relations and form of address in the Canterbury Tales. In Dieter Kastovsky \& Arthur Mettinger (eds.), The history of English in a social context: A contribution to historical sociolinguistics, 135-168. Berlin: Mouton de Gruyter.

Mazzon, Gabriella. 2010. Terms of address. In Andreas H. Jucker \& Irma Taavitsainen (eds.), Historical pragmatics (Handbooks of Pragmatics 8), 351-376. Amsterdam: John Benjamins. 
Watts, Richard J. 1989. Relevance and relational work: Linguistic politeness as politic behavior. Multilingua 8(2/3). 131-166.

Watts, Richard. 1992. Linguistic politeness and politic verbal behaviour: Reconsidering claims for universality. In Richard J. Watts, Sachiko Ide \& Konrad Ehlich (eds.), Politeness in language: Studies in its history, theory and practice, 43-70. Berlin: Mouton de Gruyter.

Watts, Richard. 2003. Politeness (Key Topics in Sociolinguistics). Cambridge: Cambridge University Press.

Watts, Richard. 2005. Linguistic politeness research: Quo vadis? In Richard J. Watts, Sachiko Ide \& Konrad Ehlich (eds.), Politeness in language: Studies in its history, theory and practice (2nd edn.), xi-xlvii. Berlin: Mouton de Gruyter.

Wilcockson, Colin. 1980. Thou and ye in Chaucer's Clerk's Tale. The Use of English 31(3). 37-43. 